\title{
WHO IS EXPATRIATED BY HITLER: AN EVIDENCE PROBLEM IN ADMINISTRATIVE LAW
}

\section{ROBERT M. W. KempNer†}

Tens of thousands of the 3 I5,000 residents of the United States who are tabulated as Germans in the alien registration of $1940^{1}$ are technically not German citizens. In 1942, the persons belonging to this group had the occasion to state under oath in their application. for a certificate of identification ${ }^{2}$ that they are citizens or subjects of no country. In fact, most of these refugees from Nazi oppression are stateless and no longer owe allegiance or loyalty to the German Reich because they have been expatriated. The sole allegiance they owe is to the United States since nearly all of them have declared their intention to become citizens of the United States. Ninety percent of them live in New York, Pennsylvania, New Jersey, and California.

The question whether or not a resident of the United States belongs to this group of expatriated persons is of utmost importance to courts, alien enemy hearing boards, loyalty boards, attorneys, Federal, State, and local government agencies; $e$. g., the State, War, and Navy Departments, the Treasury, the Federal attorneys, the FBI, and the Immigration and Naturalization Service. In wartime, the answer will be essential for many legal or administrative decisions, e. g., for the admittance of an immigrant to the United States, naturalization of a German born person, permits for employment in certain defense plants, control of travel, supervision of blocked accounts, searches of homes, special assignment in the services of the armed forces. Even the community relations to a German born might depend on the answer to the question whether Adolf Hitler claims him as his subject, because the expatriation is the only legal proof that he owes no loyalty to the Third Reich. This evidence can be corroborated by other documentary or testimonial evidence of the anti-Nazi attitude of the respective person.

Under these circumstances, it is important for our public officials and attorneys as well as for the respective aliens themselves to know who has the legal right to state under oath that he is expatriated by Hitler.

† Staff Member, Institute of Local and State Government, University of Pennsylvania; former Legal Adviser to the pre-Hitler Prussian State Police Administration; Director and Professor of Political Science, Fiorenza College, Florence and Nice; Author of POLICE ADMINISTRATron CODE (1932), The Enemy Alien Problem in the Present War (1940), Hitler's Criminal Code (1942).

The author acknowledges the suggestions of Federal attorneys. (I942).

I. Alien Registration Act, 1940, 54 STAT. 673 (1940), 8 U. S. C. A. $\$ \S 451-460$ I942).

2. See the President's Proclamation of January 14, I942, 7 FED. REG. 329 (Jan. I7, 
In April, I933, three months after the National Socialists came to power, Hitler made the political decision that proven or potential enemies of the regime should lose their German citizenship and that their property should be confiscated by the State. The jurisdiction of the Nazi police administration in this field was established and no judicial review or legal recourse was allowed.

First started the expatriation of political foes who had escaped to foreign countries. In this group we can find such names as Albert Einstein, Nobel prize winner; Thomas Mann, Heinrich Mann, Lion Feuchtwanger, Leonhard Frank, Konrad Heiden, famous writers and authors; Dr. Friedrich Wilhelm Foerster, Dr. Emil I. Gumbel, Dr. Sigfried Marck, university professors; Dr. Georg Bernhard, Dr. Manfried Georg, Dr. Carl Misch, Leopold Schwarzschild, anti-Nazi editors; Albert Grzesinski, Wilhelm Sollmann, Friedrich Stampfer, Gerhard Seger, Siegfried Aufhaeuser, famous political figures of the Weimar Republic; and the names of former high government officials, deputies, lawyers, and judges. A few thousand of this first group are now residents of the United States.

The expatriation of this group is based on the German law of July I4, I933. ${ }^{3}$ Section two of this law provides the expatriation of refugees who violated the required allegiance to the Third Reich. Every exile of this category is listed in the Official German Register Der Reichsanzeiger. If the person in question is not in the possession of the issue in which his name is listed, the Reichsanzeiger can be looked up in the Library of Congress or in the Public Library of New York. All issues edited before October, 194I are thus available. An exact and reliable compilation of the names of all exiles, expatriated before January I, I939 has been published by Dr. Carl Misch, New York; a copy of this catalogue is in the files of the Department of Justice and in those of the author of this article.

\section{II}

A second step was the denaturalization of racially or politically undesirable persons naturalized by the administration of the Weimar Republic between November, rgr8 and January, 1933. This group is mainly composed of persons born in the territories of the former Austrian-Hungarian Monarchy, who had become residents of Germany

3. German Denaturalization and Expatriation Law of July I4, I933, I REICHSGESETZBLATT 480 (I933). 
between I880 and I928. Only a few hundred of this group are now in the United States.

The denaturalization of this group is also based on the German law of July I4, r933. Section one of this law provides the possibility of the denaturalization of persons whose naturalization is undesirable according to the new Nazi racial, political, and cultural ideology. Persons of this group can also easily prove their statelessness because their names are likewise listed in the Official German Register Der Reichsanzeiger. Since all procedures of denaturalization of this kind terminated on December 3I, I935, only the Official German Register from July, I933 until January I, I936 need be consulted.

III

The time of individual expatriations was followed in I94I by a general expatriation of all refugees from Germany who were of Jewish race, and of all Jews deported to Hitler's ghettos in Axis dominated countries. Most expatriated people who are now residents of the United States belong to this group.

Their expatriation is based on the eleventh decree, issued on November 25, I $_{4}$ I, $^{4}$ for the execution of the famous Nuernberg Law of September I5, I935. ${ }^{5}$

Section one of this decree states: "A Jew who has his ordinary residence abroad cannot be a citizen of the German Reich. Ordinary residence abroad is presumed when a Jew lives abroad under circumstances which indicate that his stay is not merely a temporary one." According to Section two of the decree a Jew lost his citizenship on November 26 , I94I if on that day he had his ordinary residence abroad. Jews who take up ordinary residence abroad later will lose their citizenship at that time. The assets of all these expatriated are expropriated by the Reich when the loss of citizenship occurs. The expatriated Jews cannot acquire anything from a German citizen by reason of death or otherwise, not even from their own parents if the parents still live in Germany.

In contrast to the expatriation of political foes, and to the denaturalization of racially undesirable naturalized persons, the expatriation of the German born Jews is a general measure. Therefore, the names of the Jews expatriated according to the decree of November, I94I have not been published. In order to confirm the statement of an immigrant that he is expatriated because of his Jewish race, it is necessary to determine whether or not the respective person is a Jew according to Nazi law.

4. I REICHSGESETZBLATT No. I33 (I94I).

5. I REICHSGESETZBLATT IT46 (I935). 
The Nazi definition of a Jew for this purpose is given by the first decree, issued on November $14,1935,{ }^{6}$ for the execution of the Nuernberg Law of September I5, I935. Section five of this decree, giving the definition, reads as follows: "A Jew is a descendant of at least three Jewish grandparents in spite of his own faith or religion. Furthermore persons with two Jewish grandparents have to be considered as Jews, if they are members of a Jewish community or married with a Jew."

How can it be determined whether or not a former resident of Germany who has immigrated to the United States is a Jew as defined in the Nuernberg law? The best sources of information are the birth or marriage certificates which are part of the immigration record. In most cases the religion of the parents or man and wife is recorded. Other sources are copies of baptismal or synagogue records, and the sworn testimony of reliable former co-members of the respective community or of other persons who knew the immigrant or his family in Germany. Therefore, in the overwhelming majority of all cases our alien control agencies can prove relatively easily whether the statement "expatriated by the Nazis because of Jewish race" is correct or not.

\section{IV}

A fourth group of stateless, former Germans are the few who lost their citizenship under the provisions of the Sections I8-28 of the German Citizenship Law of July 22 , $1913,{ }^{7}$ which is still in force. According to this law, the loss of citizenship occurs:

(a) if a German citizen applies for denationalization and his application is accepted-denationalization will not be granted to persons of military age;

(b) if a German woman marries a non-German citizen; tions;

(c) if a German abroad does not fulfill his military obliga-

(d) if a German abroad does not return to Germany if required to do so;

(e) if a German without permit of his own government enters the services of a foreign government; and

(f) if a German abroad constantly refuses to register with the German consul, as required by the provisions of the Registration Act for Germans abroad. ${ }^{8}$ 
In these cases, the persons who claim statelessness should be able to give documentary evidence of the loss of the German citizenship. The respective documents would be a denationalization certificate of the German Reich, or a certificate proving the marriage with a nonGerman; or the publication of the expatriation in the Official German Register, Der Reichsanzeiger.

\section{V}

Besides these legal measures, the regime introduced the implicit denial of citizenship by administrative acts; $e$. $g$., by the denial of passports, birth certificates or other documents needed by Germans abroad. This group embraces minor political enemies of the Third Reich, non-Jewish wives of expatriated Jews, persons with only "25 per cent. Jewish blood," parents of expatriated political foes, and other persons not regarded as faithful to the Hitler Regime.

For administrative reasons, the Nazi government sometimes prefers this "cold" way of expatriation to a formal expatriation by decree. In these cases, it is quite difficult to establish documentary evidence. Letters or copies thereof to or from German government agencies might be of help in the investigation of these cases; furthermore, it is necessary to examine witnesses who are familiar with the political background, the political behavior, and the family relations of the respective person.

\section{VI}

Finally, a German abroad who acquires a foreign citizenship by application (not by birth) normally loses his German citizenship according to Section 25 of the German Citizenship Law.

(a) According to this section of the German Citizenship Law some thousand refugees who acquired United States citizenship between r918 and I942 lost their German citizenship. As United States citizens they are not technically enemy aliens. Even persons who have filed and sworn to their petition for second United States papers can probably be considered no longer citizens of Germany according to German municipal law.

(b) Other German refugees, now residents of the United States, have been naturalized in Britain, France, Czechoslovakia, Switzerland, Liechtenstein, and the South American Republics where they lived for some years before their immigration. This group also lost their German citizenship by acquiring another citizenship. But since they are natives of a hostile country, and not United States citizens, they are technically enemy aliens under Section $2 x$ of Title 50 of the United States Code and the Proclamations of the President of December 7, 
and 8, I94I. However, they are exempted from the travel, radio, etc. restrictions, and from the enemy alien registration of 1942 by a ruling of the Department of Justice of February 9, I942, released to the Press the same day.

All persons who lost their German citizenship by naturalization must be able to show their naturalization papers or respective documents. This would be sufficient evidence for the loss of German citizenship.

\section{VII}

Not to be confused with these different groups of expafriated (I-6) are the Nazi-followers abroad who retained their German citizenship and allegiance despite their naturalization in the United States. Such dual citizenship is provided by Section 25 of the German Citizenship Law. It is granted only to trustful members of Nazi organizations abroad for "economic reasons" ${ }^{9} ;$ e. g., to members of the Foreign Section of the National Socialist Party, of the German Labor Front, and similar organizations which are, according to Nazi public law, parts of the administrative machinery of the Third Reich. Germans naturalized in the United States who have sustained their allegiance to the Third Reich by retaining their German citizenship or by joining Nazi-affiliated organizations have violated their oath of allegiance to the United States. The cancellation of the citizenship certificate on the ground of fraud according to Section 338 (a) of our Nationality Act of $1940^{10}$ will be the necessary consequence.

\section{VIII}

In conclusion: in the overwhelming majority of the cases mentioned in the groups I- 6 , evidence of expatriation can be established. Sometimes the assistance of an expert in German administrative law will be needed.

The expatriation decrees of Hitler are political and racial measures of the Nazi regime; the persons concerned were his first targets. They are the people whom the Nazis attacked long before Pearl Harbor. They are people of various creeds, Jews and Gentiles, workers and merchants, writers and preachers, teachers and students. Technically, many of them are called persons of enemy nationality, but legally they are persons formerly of enemy nationality, now politically loyal partisans of the United States.

9. Secret Circular of 1938 , issued by the Ministry of the Interior, Berlin, in connection with the Anslandsorganisation der NSDAP.

Io. 54 Stat. II58 (I940), 8 U. S. C. A. \$738(a) (I942). 